\title{
Konsep dan Implementasi Manajemen Pendidikan Islam dan Ekonomi Syariah di
} Asia Tenggara

\author{
Musta'an \\ Universitas Sahid Surakarta \\ Email: mustaan-usahidh@gmail.com
}

\begin{abstract}
The purpose of this study is to understand the concepts and implementation of Islamic education and Islamic economic management in Southeast Asia, where the object of this research is the management of Islamic education and Islamic economics in Indonesia and Malaysia. The research method uses the literature study method using a historical approach. By using these methods and approaches the concepts and implementation of Islamic education and Islamic economic management in Southeast Asia (in Indonesia and Malaysia) are expected to build a clear picture through various theories that have existed and developed previously. The results show that there are various similarities between the concepts and implementation of Islamic education management and Islamic economics in Indonesia and Malaysia, which are geographically close together so that they experience the same historical phases caused by the stages of the period of international civilization. Another thing that causes similarities is that the two countries are both in the development of sharia economics which continues to grow, although until now the development of the sharia economy in Malaysia, especially the banking industry has developed much more rapidly than in Indonesia.
\end{abstract}

Keywords: concept, implementation, management of Islamic education, Islamic economics

Saran Sitasi: Musta'an. (2020). Konsep dan Implementasi Manajemen Pendidikan Islam dan Ekonomi Syariah di Asia Tenggara. Jurnal Ilmiah Ekonomi Islam, 6(02), 389-395. doi: http://dx.doi.org/10.29040/jiei.v6i2.1188

DOI: http://dx.doi.org/10.29040/jiei.v6i2.1188

\section{PENDAHULUAN}

Negara-negara di Asia Tenggara terutama negara Indonesia dan negara Malaysia memiliki berbagai keunikan dalam kaitannya dengan perkembangan manajemen pendidikan dan ekonomi yang dilakukannya. Bagi kedua negara itu, metode pendidikan yang digunakan menjadi suatu cara yang tepat dalam mencapai tujuan negara masing-masing terutama dalam meningkatkan kualitas sumber daya manusianya (lahir et.al, 2017). Sejalan dengan hal tersebut berarti yang menjadi kunci utama bagi kemajuan negara masing-masing adalah SDM yang dimiliki dari negara itu melalui pendidikan. Sebab sampai saat ini manajemen pendidikan, terutama manajemen pendidikan yang terintegrasi, sistematis, dan terstruktur secara baik menjadi motor penggerak dalam peningkatan kualitas baik kualitas secara intelektual maupun kualitas spiritual yang diharapkan akan tercipta pula kualitas moral (Wekke, 2013). Sedangkan ekonomi kedua negara saat ini sedang dalam pengembangan ekonomi yang berdasarkan prinsip-prinsip syariah Islam, terutama dari sisi perkembangan perbankannya maupun pasarmodalnya. Dimana sistem ekonomi yang dikembangkan merupakan sistem ekonomi yang berkeadilan dengan mengacu kepada al-Qur'an dan Sunnah Rasulullah SAW.

Pendidikan menjadi penopang utama bagi pembangunan, perkembangan serta peradaban yang ada suatu negara, melalui pendidikan inilah terutama dengan manajemen yang baik membuka jalan secara luas dan leluasa bagi warga negaranya dalam rangka penguasaan terhadap ilmu pengetahuan, berbagai bidang keterampilan, dan penguasaan terhadap perkembangan teknologi yang ada. Oleh karena demikian itulah, pendidikan nasional dari masingmasing negara merupakan sistem pola tersendiri yang diselenggarakan untuk mewujudkan setiap hak dalam menentukan nasib bangsa itu sendiri demi perkembangan dan kemajuan bangsanya (Mudyaharjo, 2010). Pendidikan memiliki peran serta fungsi yang sangat penting dalam mencetak generasi yang mampu 
bersaing secara baik di tengah persaingan era industri 4.0 saat ini yang tentunya generasi yang sumber daya manusianya berkualitas. Pada era ini pendidikan tentunya diharapkan mampu mempersiapkan dengan sebaik-baiknya SDM yang bonafit dalam menghadapi setiap tantangan serta mampu merespon berbagai perubahan dan perkembangan cepat yang terjadi semakin dinamis. Oleh karena itu, pendidikan adalah kunci utama dan pertama kemajuan bangsa, baik tidaknya metode atau model pendidikan yang dilakukan akan menentukan baik tidaknya pula kualitas SDM dari generasinya, yang pada akhirnya bermuara pula pada kualitas kehidupan sehari-hari bangsa itu nantinya (Muhaimin, 2013). Dengan adanya SDM berkualitas tentunya secara ekonomi di era persaingan saat ini mampu memenangkan persaingan pasar yang ada, yang pada akhirnya pula kuat secara ekonomi negara tersebut (Tho'in, 2017); (Ybarra, 1996). Tingkat kesiapan yang dimiliki dalam menghadapi persaingan industri 4.0 dan tingkat kualitas atau mutu kehidupan bangsa merupakan tantangan dan peluang yang harus segera diupayakan serta diwujudkan melalui berbagai program dari pendidikan nasional itu sendiri. Peran serta fungsi dari pendidikan dalam kehidupan bernegara dan berbangsa sesungguhnya telah dicetuskan dan dicanangkan sejak berdirinya Negara Kesatuan Republik Indonesia, sebagaimana tertuang dalam UUD 1945, bahwa mencerdaskan kehidupan bangsa serta mengembangkan manusia Indonesia seutuhnya merupakan tujuan pendidikan nasional bangsa Indonesia.

Dalam sistem pendidikan nasional kita salah satu konsep didalamnya yaitu berupa pendidikan Islam sebagai suatu bagian yang integral dan menyatu (Romlah, 2016). Pendidikan Islam itu sendiri merupakan satu bagian dari sistem pendidikan yang tidak bisa dipisahkan atau disendirikan dari sistem pendidikan nasional, karena pendidikan Islam disini tidak sekedar hanya muncul sebagai suatu pelengkap atau komplementer dalam perjalanan yang ada pada pendidikan nasional itu sendiri, tetapi pendidikan Islam memberikan landasan serta warna dan arah yang menjadi tujuan dari pendidikan nasional tersebut. Pendidikan Islam sebagai bagian atau subsistem yang tentunya secara andil telah berkontribusi secara aktif sangat besar terhadap sistem maupun tata kelola pendidikan nasional, maka dinilai sangat menarik apabila kita senantiasa mencermati berbagai perkembangan pendidikan Islam yang sangat dinamis pada bangsa ini. Oleh karena itu, untuk lebih memahami dan mengenal konsep dan implementasi dari perkembangan pendidikan Islam, tidak ada salahnya jika kita mempelajari pula perkembangan pendidikan Islam yang ada di Asia Tenggara terutama di negara Malaysia. Sejarah kehadiran Islam yang ada di Malaysia tentunya tidak jauh berbeda dengan sejarah bangsa ini yaitu melalui berbagai aktivitas perdagangan, terutama perdagangan (aktifitas ekonomi) komoditi berbagai jenis rempah (Susanto, 2015). Sejalan dengan adanya perdagangan itulah mereka melakukan penyebaran agama Islam secara bijak pada kedua negara ini, yang tentunya hal itu menjadi sebuah awalan pula dilakukannya proses pendidikan Islam baik di Indonesia maupun di Malaysia secara berkesinambungan.

Kembali melihat perjalanan bangsa, bahwa negara Indonesia maupun Malaysia mempunyai berbagai kesamaan sebagai berikut: 1) keduanya secara mayoritas penduduknya beragama Islam; 2) keduanya pernah merasakan penjajahan yang dilakukan oleh bangsa Eropa dalam hal ini menjadi salah satu terjadinya hambatan dan masalah dalam melakukan aktivitas dakwah dan syiar Islam; 3) keduanya mempunyai berbagai kesamaan tahapan dalam proses perkembangan dinamika pelaksanaan pendidikan Islam termasuk pengembangan ekonomi syariahnya (Wardani et.al, 2013); (Haryanto, 2009).

Berdasarkan pemaparan serta uraian yang telah dijelaskan sebelumnya, penelitian ini mengangkat tema secara garis besar tentang konsep dan implementasi manajemen pendidikan Islam dan ekonomi syariah di Asia Tenggara dengan fokus bahasan utama yaitu pada negara Indonesia dan negara Malaysia yang mempunyai berbagai persamaan yang berkaitan dengan konsep dan implementasi manajemen pendidikan Islam dan ekonomi syariah ini.

\section{KAJIAN PUSTAKA}

\subsection{Manajemen Pendidikan}

Manajemen pendidikan merupakan sebuah proses berupa perencanaan, proses pengorganisasian, proses pengarahan, proses pengawasan dan proses penilaian berbagai usaha pendidikan agar mampu mencapai setiap tujuan pendidikan yang telah ditetapkan dan dibuat sebelumnya (Nata, 2012). Manajemen Pendidikan merupakan berbagai rangkaian proses atas kegiatan dan aktifitas yang menunjukkan kepada usaha untuk saling bekerjasama yang dilakukan oleh dua orang atau lebih dalam rangka untuk meraih tujuan 


\section{Jurnal Ilmiah Ekonomi Islam, 6(02), 2020, 391}

pendidikan itu sendiri yang telah ditetapkan sebelumnya (Kurniadin, 2013).

\subsection{Pendidikan Islam}

Pendidikan Islam merupakan rangkaian penyiapan setiap generasi muda dalam mengisi setiap peranan, mentransfer pengetahuan serta berbagai nilai Islam diselaraskan dan diserasikan dengan fungsi manusia itu sendiri untuk senantiasa beramal selama hidup di dunia dan akan memperoleh hasilnya kelak setelah di akhirat nantinya (Tajuddin, 2011). Pendidikan Islam merupakan suatu pendidikan yang dilakukan dengan mempunyai tujuan dalam membentuk dan mencetak setiap pribadi muslim secara utuh dan menyeluruh, melakukan pengembangan potensi yang ada pada manusia secara baik dan bertanggungjawab secara jasmaniah dan rohaniah, menumbuhkan serta mengembangkan hubungan secara harmonis individu manusia dengan Allah SWT, manusia dengan alam. Setiap manusia pribadi yang dihasilkan melalui proses pendidikan Islam yaitu mereka yang sanggup mengemban tugas dan amanah dari Allah SWT, mereka mampu memelihara serta memanfaatkan alam yang ada di sekitarnya untuk tujuan kemaslahatan (Daulay, 2014).

Pendidikan Islam sendiri sebagai bagian integral konstalasi dari pelaksanaan pendidikan nasional yang ada pada bangsa ini. Pada saat permulaan kemerdekaan bangsa Indonesia tercinta dan pemerintahannya telah mendapatan suatu warisan yang bersumber dari sistem pendidikan yang dualistis, yaitu berupa a) sistem pendidikan yang terdapat pada sekolah-sekolah umum yang bersifat dan bercorak sekuler, dimana sistem pendidikan ini tidak mengenal adanya pendidikan agama, b) sistem pendidikan Islam yang tumbuh pada masyarakat Islam dengan sendirinya (Solokin, 2012).

Pendidikan Islam merupakan suatu subsistem tersendiri dari pendidikan nasional, hal itu dapat diketahui berdasarkan pada tiga aspek penting yaitu: a) pendidikan Islam berkedudukan sebagai sebuah mata pelajaran di sekolah, b) pendidikan Islam berkedudukan sebagai lembaga, c) pendidikan Islam berkedudukan sebagai suatu nilai. Pendidikan Islam berkedudukan sebagai mata pelajaran di sekolah, bahwa materi pendidikan Islam merupakan mata pelajaran dari sekian mata pelajaran yang ada serta menjadi bagian pula dari kurikulum untuk membentuk kesalehan secara pribadi dan secara sosial. Pendidikan Islam berkedudukan sebagai suatu lembaga, dimana pendidikan Islam yang ada selama ini telah dipandang oleh masyarakat sebagai jenis lembaga pendidikan yang ada bercorak keislam mulai dari bahan pelajaran yang telah diajarkan, metode yang digunakan dalam penyampaian bahan ajar tersebut, serta jenis pengelolaan yang dilakukan. Pada aspek tersebut tentunya kita mampu melihat secara sesama bahwa lembaga pendidikan Islam berada pada rel bersifat formal maupun rel bersifat nonformal. Pendidikan Islam berkedudukan sebagai suatu nilai, dimana pendidikan Islam dipandang sebagai sebuah semangat tersendiri yang secara implisit telah diselipkan pada mata pelajaran yang ada, kegiatan serta pengabdian kepada masyarakat pada bidang pendidkan secara komprehensip dan menyeluruh (Daulay, 2014).

\subsection{Ekonomi Syariah}

Ekonomi syariah atau ekonomi Islam merupakan sistem ekonomi yang didasarkan pada prinsip-prinsip syariat Islam dengan salah satu cirinya berupa sistem ekonomi non ribawi (Tho'in, 2016); (Wilson, 1998).

Sistem ekonomi syariah yang ada di Indonesia dan di Malaysia sedang mendapatkan perhatian khusus baik oleh pemerintahnya maupun oleh rakyatnya.

\section{METODOLOGI PENELITIAN}

Jenis penelitian yang dilakukan saat ini merupakan jenis penelitian yang bersifat kualitatif melalui penggunaan metode berupa studi pustaka dengan menggunakan pendekatan historis. Dengan menggunakan metode dan pendekatan tersebut diharapkan konsep dan implementasi manajemen pendidikan Islam dan ekonomi syariah di Asia Tenggara (di Indonesia dan Malaysia) diharapkan bisa terbangun suatu gambaran yang jelas melalui berbagai teori yang sudah ada dan dikembangkan sebelumnya.

\section{HASIL PENELITIAN}

\subsection{Konsep dan Implementasi Manajemen Pendidikan Islam dan Ekonomi Syariah di Indonesia}

Pendidikan Islam bangsa ini telah mengalami perkembangan yang terbagi dalam empat fase, yaitu: 1) sejak pertama Islam datang sampai dengan kedatangan bangsa Belanda saat menjajah bangsa ini. 2) sejak kedatangan Belanda sampai timbulnya berbagai gagasan pembaharuan dalam pendidikan Islam awal abad 20.3) sejak awal abad 20 sampai saat 


\section{Jurnal Ilmiah Ekonomi Islam, 6(02), 2020, 392}

datangnya kemerdekaan bagi bangsa Indonesia. 4) fase setelah bangsa ini merdeka.

Perjalanan proses Pendidikan Islam pada awal, dimulai dari kedekatan yang terjadi antara pribadi maupun secara bersama-sam antara para peserta didik (santri) dengan mubaligh. Masjid dan rumah kyai menjadi tempat dilakukannya pendidikan Islam. Setelah dua tempat tersebut mulai bermunculan lembaga pendidikan yang lain seperti pondok pesantren, surau dan dayah. Materi yang diajarkan dan disampaikan pada saat itu berupa ilmu-ilmu keagamaan khususnya membaca dan mempelajari berbagai kitab terutama kitab-kitab klasik. Kitabkitab klasik tersebut menjadi standar untuk mengetahui tingkat keilmuan agama para kyai tersebut.

Sejak kedatangan Belanda sampai timbulnya berbagai gagasan pembaharuan dalam pendidikan Islam awal abad 20. Bangsa penjajah ini mendirikan berbagai lembaga pendidikan sekuler bagi bangsa asing Eropa yang ada di Indonesia. Tujuan utama diselenggarakannya pendidikan ini untuk mempersiapkan calon pegawai kantor pemerintah Belanda. Keberadaan lembaga ini hanya terdapat pada perkotaan. Berbeda dengan keadaan tersebut dimana lembaga pendidikan yang bersifat tradisional justru bermunculan di pedesaan-pedesaan. Pendidikan tradisional ini mengajarkan pengetahuan agama Islam, tanpa memberikan pengetahuan umum. Lembaga pesantren sepenuhnya dikelola berdasarkan ide dan pengaruh kyai sebagai pengasuhnya. Sistem pendidikan pesantren dengan corak kesederhanaannya seringkali melahirkan sentimensentimen anti penjajah karena berlawanan dalam berbagai hal.

Fase ketiga dimulai di awal abad kedua puluh ketika munculnya ide-ide pembaharuan pendidikan Islam disebabkan ketidakpuasan beberapa tokoh dengan sistem pendidikan yang berlaku saat itu. Pada periode ini dikenal adanya dualisme sistem penddikan yang corak dan orientasinya berbeda. Pertama, pendidikan Barat yang sekuler yang dikelola secara cermat oleh pemerintah Belanda. Cermat karena memiliki jenjang dan muatan mata pelajaran yang sistematis. Pendidikan ini diperuntukkan bagi kaum asing Eropa dengan muatan keilmuan dari Barat dan tidak mengajarkan pelajaran agama. Kedua, pendidikan Islam yang diselenggarakan di pesantren, mengajarkan ilmu-ilmu agama tanpa mempelajari pengetahuan umum. Lembaga ini mendidik seseorang untuk menguasai ilmu agama dan mampu hidup mandiri di tengah masyarakat. Oleh karena itu ide-ide baru yang mereka munculkan adalah pembaharuan pada aspek isi, metode, dan manajemen.

Jadi sejak awal abad kedua puluh terdapat tiga lembaga pendidikan Islam sebagai konsekuensi dari dinamika perkembangan, yakni pesantren, sekolah, dan madrasah. Pesantren sebagai lembaga pendidikan Islam tertua, berupa lembaga pendidikan yang materi pelajarannya didominasi oleh keilmuan agama dan keterampilan kehidupan tanpa pengetahuan umum. Sekolah, sejak belum diajarkannya pelajaran agama pada zaman Belanda sampai dimasukkannya pendidikan agama di sekolah-sekolah umum setelah Indonesia merdeka. Madrasah yang pada mulanya memberi penekanan pada bidang-bidang ilmu agama dan hanya berkiprah hanya di lingkungan Departemen Agama saja sampai ditetapkannya madrasah sebagai lembaga pendidikan yang berciri khas agama Islam dan berkedudukan sama dengan sekolah.

Fase keempat setelah Indonesia merdeka, direalisasikan kerjasama antara Departemen Agama dengan Departemen Pendidikan dan Kebudayaan untuk menerapkan pendidikan Agama di sekolah. Dalam konteks kerja sama ini dapat dibedakan dalam tiga tahapan. Tahapan pertama 1946-1966, sebagai tahapan peletakan dasar dari pendidikan agama di sekolah. Tahapan ini berupa pencarian bentuk dan masa pembinaan awal.

Tahapan kedua adalah tahapan setelah diadakannya Sidang Umum MPRS 1966, dimana dalam TAP MPRS No. XXVII/MPRS/1966 pasal 1 menetapkan Pendidikan Agama menjadi mata pelajaran di sekolah-sekolah mulai dari sekolah dasar sampai ke universitas-universitas negeri.

Tahapan ketiga adalah tahapan diberlakukannya Surat Keputusan Bersama Tiga Menteri tahun 1975 (Menteri Agama, Menteri Pendidikan dan Kebudayaan, dan Menteri Dalam Negeri).

Tahapan keempat adalah setelah diberlakukannya UU Sisdiknas (UU No.2 Tahun 1989). Madrasah pada tahapan ini dijelaskan secara eksplisit adalah sekolah yang berciri khas Agama Islam, makna yang terkandung di dalamnya bahwa madrasah mulai dari tingkat dasar dan menengah memberlakukan kurikulum sekolah ditambah dengan kurikulum ilmu-ilmu agama sebagai ciri khasnya.

Kaitannya dengan perkembangan ekonomi syariah di Indonesia di tandai dengan adanya perbankan syariah. Cikal bakal perundang-undangan 
yang dijadikan pedoman pengoperasian adalah Undang-Undang No. 07 Tahun 1992 tentang perbankan dan UU No. 10 tahun1998 tentang perubahan atas UU No. 07 Tahun 1992. Melalui UU itu perbankan syariah bisa beroperasi.

Pertama, Periode peletakan dasar sistem perbankan syariah (1992-1998). Periode ini merupakan awal berdirinya dari Bank Syariah di Indonesia yaitu Bank Muamalah Indonesia (BMI). Yang diprakarsai oleh para cendekiawan muda dalam organisasi ICMI dan dukungan MUI. UU No. 07 Tahun 1992 tentang perbankan disahkan. Tepatnya pada 25 Maret 1992 Oleh Presiden RI.

Kedua, Periode reformasi kebijakan perbankan Islam (1998-1999). Lahirnya UU no. 101998 memberikan peluang yang sangat luas bagi perbankan Islam. Yaitu pengakuan secara tegas terhadap pembiayaan berdasarkan syariah baik di bank Umum maupun Bank Perkreditan Rakyat.

Ketiga, Periode terbentuknya UU no.21 thn 2008 (1999-2009). Pada tanggal 17 Juni 2008 RUU Perbankan Syariah disahkan menjadi Undang-Undang oleh ketua DPR Agung Laksono. Sebulan kemudian tepatnya pada tanggal 16 Juli 2008, Presiden Susila Bambang Yudhoyono mengesahkan UU perbankan Syariah dengan No. 21 Tahun 2008 yang dimuat dalam lembaran negara RI Tahun 2008 nomor 94. dengan terdiri dari 13 bab dan 70 pasal.

Sampai saat ini perkembangan ekonomi Islam mengalami kemajuan dari sisi pertumbuhan, tetapi masih tertinggal dengan perkembangan ekonomi Islam yang ada di Malaysia yang jauh lebih cepat berkembang karena dukungan itu ada pada sistem kebijakan sampai ilmplementasi di lapangannya.

\subsection{Konsep dan Implementasi Manajemen Pendidikan Islam dan Ekonomi Syariah di Malaysia}

Perkembangan pendidikan Islam di Malaysia dapat dirinci menjadi tiga periode, (1) masa awal masuknya Islam ke Tanah Melayu sampai dengan datangnya bangsa kolonial, (2) masa penjajahan kolonial Inggris, dan (3) masa pasca kemerdekaan sampai sekarang.

Awal mula perkembangan pendidikan Islam masih belum dapat dipastikan, hanya saja dapat diperkirakan bahwa seiring dengan datangnya Islam di tanah Melayu pada abad ke-14 pada saat itu pula pendidikan Islam dimulai. Hal ini didasarkan pada fakta sejarah bahwa Raja Malaka pertama yang bernama Parameswara yang kemudian dikenal sebagai Megat Iskandar Syah setelah memeluk Islam pada tahun $1414 \mathrm{M}$, maka saat itulah dimulai sistem pendidikan Islam di Tanah Melayu. Masuknya Islam sang raja diikuti oleh para pembesar kerajaan beserta rakyatnya. Dalam upaya memahami kandungan ajaran Islam, raja dan pembesar kerajaan belajar dari para ulama dan pendakwah yang datang ke Malaka. Raja-raja Malaka yang lain mengikuti jejak Raja Malaka untuk memeluk Islam. Pada saat itu istana kerajaan dijadikan pusat kegiatan pendalaman keilmuan Islam karena begitu cintanya raja beserta rakyat terhadap ajaran Islam.

Sistem pendidikan Islam pada awalnya berbentuk kelas mengaji al-Qur'an, yang merupakan pelajaran utama pada semua lapisan masyarakat saat itu walaupun tidak berbentuk lembaga formal. Juga diperkenalkan huruf jawi untuk memudahkan masyarakat setempat mempekajari huruf-huruf Arab yang menjadi penunjang kemampuan membaca alQur'an. Untuk tingkat-tingkat awal, kelas pengajian al-Qur'an dilakukan di rumah guru. Jika jumlah pebelajar semakin banyak, pembelajaran dilakukan di surau dan masjid. Struktur pendidikan dan kurikulumnya ditekankan pada kemampuan membaca, menulis, dan mengaji al-Qur'an. Pelajaran-pelajaran selain mempelajari al-Qur'an juga mempelajari ilmu Fiqh, Tauhid, Tafsir, Sejarah, Tasawuf, dan Filsafat Islam. Pada fase itu sistem pendidikan Islam sudah berbentuk pondok.

Masa pendudukan bangsa Barat di Tanah Melayu dimulai ketika jatuhnya Kerajaan Malaka, bangsa Melayu memasuki zaman kegelapan, perkembangan bidang ekonomi, politik, kebudayan, agama, dan pendidikan mengalami hambatan. Penaklukan bangsa Barat ke Tanah Melayu merupakan jalan utuk menghalangi perkembangan dakwah ajaran Islam sekaligus menyebarkan ajaran Kristen kepada penduduk. Sekalipun upaya penjajah untuk menyebarkan ajaran Kristen tidak berhasil.

Pada masa kekuasaan penjajah, kegiatan syiar Islam dan pendidikan Islam menjadi terhambat. Ada yang berpendapat kegiatan dakwah pada saat itu terpaksa dilakukan secara rahasia untuk menghindari ancaman larangan dari pihak penjajah. Puncaknya ketika tahun 1854, sekolah al-Qur'an yang berbentuk pondok mulai diambil alih pemerintah Inggris. Sekolah-sekolah agama diberi bantuan penuh oleh pemerintah tetapi dengan syarat sekolah itu harus memberikan pelajaran membaca menulis dan 


\section{Jurnal Ilmiah Ekonomi Islam, 6(02), 2020, 394}

berhitung disamping mata pelajaran agama dan membaca al-Qur'an. Bangunannya digunakan sebagai sekolah Melayu pada waktu pagi dan mendapat bantuan penuh dari pemerintah Inggris, selanjutnya sekolah al-Qur'an dilaksanakan pada waktu petang di tempat yang sama. Upaya ini dianggap bertujuan untuk menjauhkan pendidikan Islam dari kehidupan masyarakat setempat. Jadi pendidikan pada masa penjajahan diketahui ada dua sistem pendidikan yang berlawanan, sekolah kebangsaan sekuler dan pendidikan Islam. Sekolah kebangsaan sebagai sistem pendidikan yang mendapat dukungan penuh penguasa namun kurang mendapat sambutan dari bangsa Melayu karena dianggap dapat merusak aqidah putra-putrinya. Di sisi lain sistem pendidikan Islam yang berbentuk pondok tidak diakomodasi oleh penguasa namun tetap diminati masyarakat setempat.

Upaya pemerintah Inggris yang membuka sekolah Melayu di pagi hari awal mulanya kurang mendapatkan sambutan positif dari masyarakat. Namun pihak penguasa tidak putus asa, mereka memberikan iming-iming bahwa para lulusan sekolah Melayu nantinya akan dipekerjakan sebagai pegawai, polisi dan sebagainya. Akhirnya pada penghujung tahun 1930-an golongan orang Melayu mulai tertarik untuk megikuti sekolah di sekolah Melayu dan sekolah Inggris. Walaupun pihak penjajah dapat mendirikan sekolah Melayu dan menyingkirkan sekolah al-Qur'an di waktu petang, namun masyarakat Melayu tetap mempertahankan asas pendidikan Islam yang menjadi warisan agama dan bangsa. Mereka berhasil mempertahankan institusi tradisional. Sistem pendidikan Islam masih menjadi pilihan utama para pemuda. Bahkan beberapa melanjutkan ke jenjang pendidikan yang lebih tinggi ke luar negeri, seperti Pattani, Mekkah, Mesir, dan negara Islam lain.

Lembaga pendidikan Islam semula berbentuk pondok dengan tempat belajar mengajar memanfaatkan masjid, kemudian berkembang menjadi madrasah atau sekolah agama yang dilengkapi bangunan sekolah, asrama, kantor pengurus, dan fasilitas rekreasi. Pembaharuan pandangan dalam memahami dan mempelajari Islam dibawa oleh para pelajar yang baru lulus dari Universitas Al Azhar, bahwa memahami Islam harus lebih utuh. Gagasan mereka dicetuskan dengan mendirikan madrasah. Salah seorang tokoh yang terlibat dalam usaha mengubah sistem pendidikan yang lebih sisematis adalah Syed Syeikh al-Hadi yangdi tahun 1906 mendirikan madrasah di Bukit Mertajam, Seberang Prai. Tahun 1907 berdiri Madrasah Iqbal di Singapura, dan Madrasah al-Hadi di Malaka, tahun 1917.

Tahun 1952 diterbitkan Ordonansi Pelajaran 1952 dimana pada pasal 70 diatur pelajaran agama Islam menjadi mata pelajaran di sekolah bantuan pemerintah. Pelajaran Agama Islam terus mendapat perhatian utama dalam Laporan Razak tahun 1956 yang mengusulkan agar sekolah-sekolah yang memiliki siswa beragama Islam tidak kurang dari 15 harus melaksanakan pembelajaran agama Islam. Usulan tersebut diterima oleh kerajaan dan dimasukkan dalam pasal 49, Peraturan Kerajaan tentang Pendidikan 1957.

Pada masa setelah kemerdekaan, berdasarkan rekomendasi Laporan Rahman Talib tahun 1960, Undang-undang Pendidikan tahun 1961 mewajibkan sekolah-sekolah bantuan kerajaan menyediakan pendidikan Agama Islam, anggaran belanja untuk pendidikan Islam ditanggung oleh Kementerian Pendidikan. Tahun 1962 diberlakukan ketentuan jam pelajaran pendidikan Agama Islam sebanyak 120 menit seminggu dan diberikan selama sebelas tahun siswa-siswa sekolah. Di Malaysia segala permasalahan Agama Islam ada di bawah pengawasan Yang Dipertuan Agong dan Raja-raja Melayu, bahan pelajaran Pendidikan Islam disetujui oleh Majelis Raja-raja sebelum diterapkan di sekolahsekolah.

Sebuah komite dibentuk pada tahun 1967 yang terdiri dari wakil Kementerian Pendidikan, perguruan tinggi Islam, dan Sekolah-sekolah Agama Kerajaan Negeri untu menyusun bahan pelajaran pendidikan Islam. Bahan pelajaran tersebut mulai dilaksanakan pada tahun 1968. Isi materi pelajaran disesuaikan dengan taap usia siswa dan kemampuan berfikir mereka.

Mata pelajaran pendidikan Islam diperkuat lagi dengan menerapkan program $\mathrm{j}$ - QAF singkatan dari jawi, al-Qur'an, bahasa Arab, dan fardlu ain, program yang bertujuan memperkuat penguasaan jawi, memastikan siswa khatam al-Qur'an di sekolah rendah, mewajibkan pelajaran Bahasa Arab, dan memantapkan amalan dan penghayatan ibadah. Program ini mulai dilaksanakan pada tahun 2005.

Kaitannya dengan perkembangan ekonomi syariah di Malaysia, Industri keuangan syariah di Malaysia sempat diragukan perkembangannya. Namun, kini industri yang menjalankan kaidah Islami 
ini berkembang pesat selama tiga dekade ini. Dilansir dari The Star, Selasa 12 April 2016, penulis Ikim's Center for Economics and Social Studies, Mohamad Azhar Hashim, mengatakan Negeri Jiran ini berhasil menciptakan iklim yang kondusif dan komprehensif bagi ekonomi syariah. Caranya, menciptakan instrumen syariah, infrastruktur keuangan syariah, dan regulasi untuk ekononomi ini. Tak hanya itu, Malaysia juga meningkatkan kualitas sumber daya manusia (SDM) untuk mendukung pengembangan industri keuangan syariah. " Upaya ini menjadikan Malaysia menjadi pemimpin ekonomi Islam.

Dia mengatakan kisah sukses Malaysia dalam membangun dan meningkatkan sistem keuangan syariah ini adalah penerapan ajaran Islam secara moderat. Semangat ini tecermin dari tahap-tahap pembangunan keuangan syariah dan diperlihatkan oleh harmonisasi, kerja sama, dan kolaborasi antara pemerintah, institusi Islam, dan pemangku kepentingan lainnya. Dengan cara inilah perbedaan pendapat terhadap ketetapan dan aturan syariah dalam transaksi keuangan, bisa diterima. Dengan hal tersebut akhirnya malaysia di Asia Tenggara sampai saat ini memiliki perkembangan ekonomi Islam yang paling signifikan di bandingkan negara-negara yang lain.

\section{KESIMPULAN}

Sejarah dan perkembangan pendidikan Islam dan ekonomi syariah di Indonesia dan Malaysia memiliki banyak kesamaan, hal ini disebabkan oleh letak geografis yang berdekatan sehingga mengalami fasefase sejarah yang sama yang disebabkan oleh tahapan periode peradaban internasional. Hal lain yang menyebabkan kesamaan adalah kedua negara samasama sedang dalam perkembangan ekonomi syariah yang terus tumbuh, meskipun sampai saat ini perkembangan ekonomi syariah di Malaysia terutama industri perbankannya mengalami perkembangan jauh lebih pesat dibandingkan yang ada di Indonesia.

\section{REFERENSI}

Daulay, Haidar. Pendidikan Islam dalam sistem pendidikan nasional di Indonesia. Kencana, 2014.

Haryanto, Budi. Pendidikan Perbandingan, Dalam Rintisan Corak Keilmuan dan Kepraktisan, Universitas Muhammadiyah Sidoarjo, 2009.
Kurniadin, Machali, I., \& Sandra. Manajemen pendidikan: konsep \& prinsip pengelolaan pendidikan. 2013.

Lahir, Sri; Ma'ruf, Muhammad Hasan; Tho'in, Muhammad. Peningkatan Prestasi Belajar Melalui Model Pembelajaran Yang Tepat Pada Sekolah Dasar Sampai Perguruan Tinggi. Jurnal Ilmiah Edunomika, 2017, 1.01.

Mudyahardjo, Redja. Pengantar Pendidikan. Jakarta: Rajawali Press, 2010.

Muhaimin. Rekonstruksi Pendidikan Islam. Jakarta: Rajawali Press, 2013.

Nata, HA. Manajemen Pendidikan: Mengatasi Kelemahan Pendidikan Islam di Indonesia. Kencana, 2012.

Nabhan, Faruqon. "Sistem Ekonomi Islam." Terj. Muhadi Zainuddin. UII Pres. Yogyakarta (2000). Romlah. Manajemen Pendidikan Islam. Bandar Lampung: Harakindo Publishing, 2016.

Solokin, M M. Rekonstruksi Pendidikan Pesantren sebagai Character Building menghadapi Tantangan Kehidupan Modern. KARSA: Journal of Social and Islamic Culture, 2012, 20.1: 58-74.

Susanto. Perbandingan Pendidikan Islam di Asia Tenggara. Jurnal Pendidikan Islam IV, 2015.

Tajuddin Nur. Perbandingan Tujuan Pendidikan Islam dengan Pendidikan Barat. Majalah Ilmiah Solusi, 2011.

Tho'in, Muhammad. "Larangan Riba Dalam Teks Dan Konteks (Studi Atas Hadits Riwayat Muslim Tentang Pelaknatan Riba)." Jurnal Ilmiah Ekonomi Islam 2.02 (2016).

Tho'in, Muhammad. Pembiayaan Pendidikan Melalui Sektor Zakat. Al-Amwal: Jurnal Ekonomi dan Perbankan Syari'ah, 2017, 9.2.

Wekke, Ismail. Lembaga Pendidikan Sebagai Pilar Dakwah di Wilayah Minoritas Muslim. Jurnal Dakwah Alhikmah, 2013.

Wardani, H. K., \& Tho'in, M. (2013). Pengelolaan Baitul Maal Dalam Meningkatkan Kesejahteraan Negara. Jurnal Akuntansi dan Pajak, 14(01).

Wilson, Rodney. "The Contribution of Muhammad Baqir Al-Ṣadr to Contemporary Islamic Economic Thought." Journal of Islamic Studies 9.1 (1998): 46-59.

Ybarra, Josep-Antoni. "The Zaqât in Muslim society: an analysis of Islamic economic policy." Social science information 35.4 (1996): 643-656. 